Johnston, Alan ORCID:

https://orcid.org/0000-0003-4796-466X (2016) Motivation and the academic - where the drivers sit. Journal of Management Development, 35 (6). pp. 765-777.

Downloaded from: http://ray.yorksj.ac.uk/id/eprint/1586/

The version presented here may differ from the published version or version of record. If you intend to cite from the work you are advised to consult the publisher's version: http://www.emeraldinsight.com/doi/pdfplus/10.1108/JMD-09-2015-0140

Research at York St John (RaY) is an institutional repository. It supports the principles of open access by making the research outputs of the University available in digital form. Copyright of the items stored in RaY reside with the authors and/or other copyright owners. Users may access full text items free of charge, and may download a copy for private study or non-commercial research. For further reuse terms, see licence terms governing individual outputs. Institutional Repository Policy Statement

\title{
RaY
}

Research at the University of York St John

For more information please contact RaY at ray@yorksj.ac.uk 


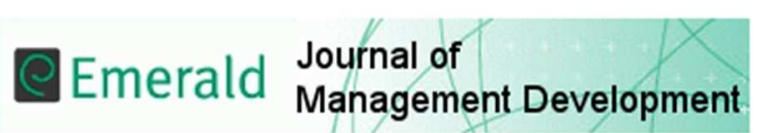

\section{Motivation and the academic - where the drivers sit}

\begin{tabular}{|r|l|}
\hline Journal: & Journal of Management Development \\
\hline Manuscript ID & JMD-09-2015-0140.R1 \\
\hline Manuscript Type: & Original Article \\
\hline Keywords: & academics, motivational drivers, Higher education \\
\hline \multicolumn{2}{|l}{} \\
\hline
\end{tabular}

SCHOLARONE ${ }^{\text {m }}$

Manuscripts 
Motivation and the academic - where the drivers sit

\begin{abstract}
Purpose - This paper investigates the key drivers for motivation within a small team of academics within a relatively small UK University.

Design/methodology/approach - The research follows a combined interpretivist and ethnographic stance and using a mixed methods approach.

Findings - The research identifies that fundamentally academics are driven by the desire for expertise and a search for meaning, while material reward and a need for power play a low significance in their forces. Also increase in managerialism has led to reductions in motivation.
\end{abstract}

Research limitations/implications - The paper provides a limited focus due to the nature of being a small scale study.

Practical implications - The paper considers the drivers which motivate academics. Managers and HR departments may consider approaches to managing and leading individuals to achieve improved organisational performance.

Originality/value - The paper focuses on motivational drivers within the academy

Keywords - academics, motivational drivers, higher education

Paper type - research paper 


\title{
Introduction
}

\begin{abstract}
The higher education sector within the UK is going through a period of significant upheaval and change, some of it externally imposed, some internally. As the sector changes, so does the role of the academic and most importantly the engagement of the academic with their host institution. This engagement is signified by the psychological contract and is a key determinant into how much discretionary effort is put into the role by the individual. Arguably the formal expression of this is motivation. This research seeks to identify the key drivers influencing motivation levels of a single team of academics at a relatively small Higher Education Institution (HEI).
\end{abstract}

A continuing theme of higher education is quality and the student experience. Governments have continually sought to control and influence the sector and developed a series of measures and strategies to place the student at the centre of the process. During all this there has been limited analysis of the role of the academic in ensuring that this is achieved. This paper seeks to analyse the view of what makes an academic tick, and how that influences the teaching and learning process. Rowley (1996) argues that the motivation of academics is crucial in the development of quality in education. Bathmaker (1999) and Gammie (2006) both highlight the impact of managerialism on the motivation of academics, while Parr (2014) reports on the negative impact the Research Excellence Framework (REF) has had.

\section{Literature Review}

The range of motivation theories generally split into two classifications, content and process theories (Mullins, 2005). Content theories are concerned with "what motivates individuals" 
(p 479). Several theorists have developed models to try to explain why individuals and groups behave in certain ways in given circumstances. More recently, examination of the concept of motivation has concentrated on in intrinsic and extrinsic drivers which push buttons to create activity. Intrinsic motivation is associated with psychological rewards, while extrinsic motivation is associated with tangible rewards (Mullins, 2005).

McClelland (1971 cited in Mullins, 2005) suggest three motivational drivers: achievement; affiliation; power, which influence an individual's work behaviour. The 'achievement motivated' person focusses on achievement. This could be related to achievement of specific goals, career advancement or recognition related and is often related to a need for a sense of accomplishment. The 'power motivated' individual focusses on having power or influence over others or resources and have a strong desire to make an impact, lead and for their ideas to prevail. Often these individuals feel a need towards increasing personal status and prestige. Finally the 'affiliation motivated' person has a need for friendly relationships and is motivated by interaction with other people, with a need to be liked and be popular.

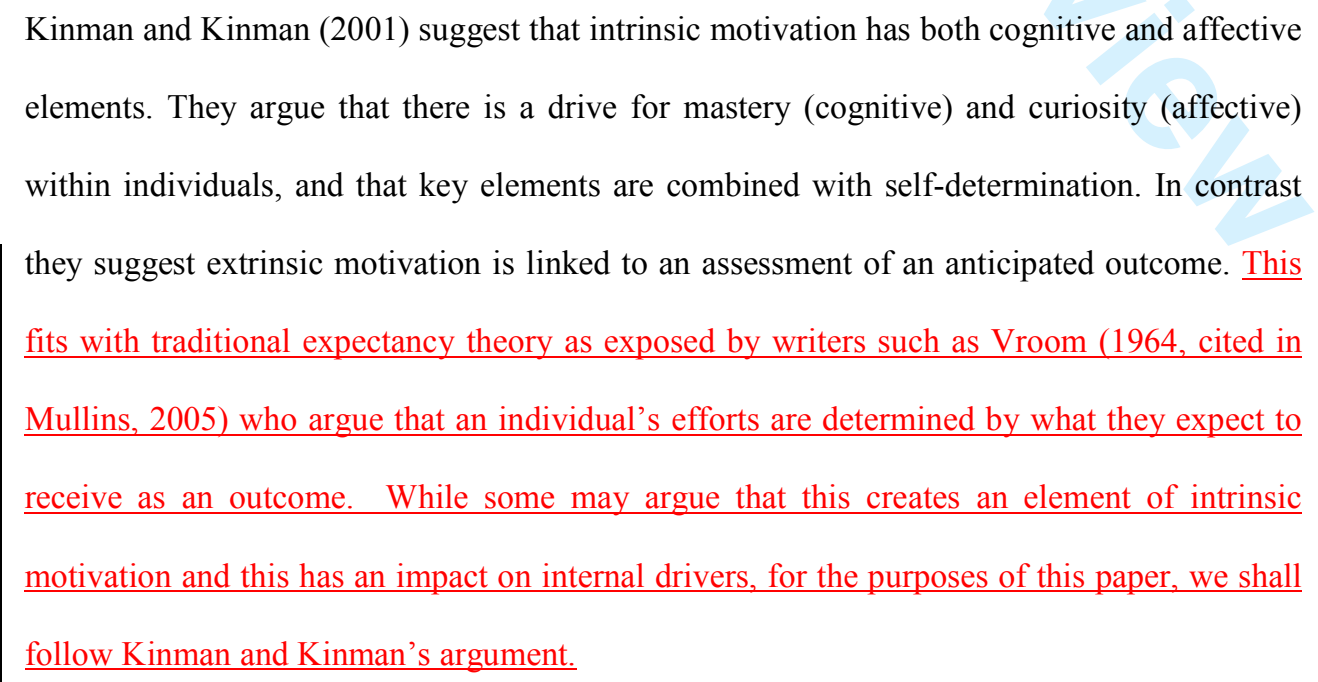
elements. They argue that there is a drive for mastery (cognitive) and curiosity (affective) within individuals, and that key elements are combined with self-determination. In contrast they suggest extrinsic motivation is linked to an assessment of an anticipated outcome. This fits with traditional expectancy theory as exposed by writers such as Vroom (1964, cited in Mullins, 2005) who argue that an individual's efforts are determined by what they expect to receive as an outcome. While some may argue that this creates an element of intrinsic motivation and this has an impact on internal drivers, for the purposes of this paper, we shall follow Kinman and Kinman's argument. 
Wilkesmann and Schmid (2014) meanwhile, suggest that the 3 key elements of intrinsic motivation are autonomy, relatedness and competence. They suggest that the ability to determine your own destiny, in the sense of making one's own decisions coupled with understanding how your role / activities fit within the wider organisation are critical. They also acknowledge that in order to create motivation, there needs to be an element of trust in your competence to do whatever it is you are intending to do. It is this self-determination of competency which is critical in determining most individuals' inherent drivers. Thus suggesting that an individual needs to feel they are competent to do something, in order to be motivated to do it.

Stringer et al (2011) positively link intrinsic motivation with job satisfaction, while extrinsic motivation is linked negatively. Coupled with this, longstanding motivation models support this notion linking job satisfaction with motivation. For example, Herzberg's (2003) two factor theory, suggests that motivators lead to job satisfaction, while hygiene leads to dissatisfaction. While, Stringer et al (2011) point to Maslow's hierarchy of needs and suggests that high levels of job satisfaction may lead to self-actualisation. This is supported by Lawrence and Jordan (2009) who suggest motivated employees tend to have higher performance levels, have higher job satisfaction levels and are more committed to the organisation. Alongside this, Furnham et al (2009) suggest that both conscientiousness and job status were key factors in predicting job satisfaction. They point to the impact of individual differences (personality and demographics) on motivation.

$R Q 1$ - what are the key drivers for academics 


\begin{abstract}
Eyal and Roth (2011) highlight the important relationship between leadership and motivation. They suggest that high levels of controlling behaviour associated with transactional leadership will have a negative effect on motivation, while transformational leadership will potentially lead to self-actualisation. It is however highlighted that transformational leadership may lead to negative consequences and the potential of fatigue and burnout if not managed correctly. Consequently, Milne (2007) points to reward and recognition systems as key elements in the motivation process. She highlights that both team and individual reward systems of both competitive and non-competitive nature can lead to increased motivation and job performance, and also emphasises the importance of creating the correct organisational culture for knowledge sharing.
\end{abstract}

\title{
Academics
}

Lawrence and Jordan (2009) emphasise the importance of motivation to both academics and managers. Beyond that if we consider academics as employees it is as important to understand their motivation, to undertake their role, as it is to understand it from a research or theoretical perspective.

Wilkesmann and Schmid (2014) highlight the need for academics to undertake three key activities: teaching; research; administration and that the key to a successful career is founded on research. They highlight that traditional thinking was that academics were "highly intrinsically motivated to teach and to do research" (p6). Andrew et al (2006) emphasise the increasing importance that Universities have placed on measuring quality of the education they provide. They suggest that lecturers are motivated to improve their teaching, so assessment of teaching and suggestions for improvement will develop an internal drive to improve and thus increase motivation. Crucially, "Quality teaching has become an 
increasingly important issue within academia" (Dahl and Smimou, 2011, p384). Wilkesmann and Schmid (2014) undertook a study among German academics, and their motivation to teach. They suggest the importance of promoting teaching as a critical organisational activity and equivalent to research in terms of prestige and esteem. Alongside this, Swift et al (2010) identify motivation as a critical factor in knowledge flow. They identify what individuals hope to achieve as crucial in providing a platform for motivation.

Coupled to this, Hackman and Oldham's (1980) Job Characteristics Model (JCM) highlight the importance of both the meaningfulness of the individual's work and the level of responsibility (identified in the level of freedom in the role) demonstrating two important facets in the drivers. Therefore whether academics place the same value on their contrasting roles will determine the level of effort placed on achieving each task.

RQ2 - how do academics relate to the different roles in terms of motivation

Rowley (1996) suggests that staff are a key resource in higher education institutions, and academic staff are crucial in achieving organisational objectives. She argues that they have a direct relationship on the student experience. This is supported by Krivokapic-Skoko and O'Neill (2008) who suggest that lecturer's motivation and enthusiasm makes a significant difference to engagement in the process, and are affected by how they see education and its purpose. They suggest there are three key roles within a lecturer's job - teaching, research and administration. In a slight contrast, although with some significant overlap, Gammie (2006) suggest that individuals may have one of three job perceptions. He suggests that some have a job orientation where the focus is on financial rewards, while others have a career orientation, with a focus on advancement, while others have a social orientation which concentrates on fulfilling socially acceptable work. 


\begin{abstract}
Mercer (2009) suggest participation in the decision making process is of high importance and that it differs between types of HEIs, and is more likely in pre-1992 universities. Mercer suggest that there is a preference for collegiality amongst academics. In support, Schimmel et al (2013) identify a link between collegiality and discretionary effort. Meanwhile, Sukirno and Siengthai (2011) in a study conducted in Indonesia, suggest that perhaps decision making is a fundamental element affecting lecturer performance and it can therefore impact on motivation. Gammie (2006) identifies fairness and justice as main issues in motivation for academics.
\end{abstract}

Rowley (1996) and identifies five strategies for motivating academic: appraisal and development schemes; opportunities for personal development; managing dis-satisfiers; financial dimension; social factor. However, Bathmaker (1999) suggests that it is difficult to motivate academics if they are not internally driven. She suggests that a number of the changes that have taken place within higher education, in particular identifying the feeling of a loss of autonomy and control has led to a fall in the motivational levels. That given she suggests that younger, career driven lecturers are more accepting of the situation.

McTavish and Miller (2009) point to the 1992 Further and Higher Education Act as a watershed moment in Education generally, but specifically on HE. This act raised a focus on the efficient use of resources with autonomous institutions based on business models. This brought with it a new managerialist approach. Although arguably Universities were already autonomous, Polytechnics and Colleges of HE often had significant local authority involvement. More recently, O’Neill et al (2010) and Creasy (2013) have all suggested that a focus of recent governments has been to shift higher education from public good to a private good (or investment), focussing on the private benefits, as opposed to the social benefits. 
Feather (2012) makes reference to the notion of the "Trojan horse" (p336) as business and government try to gain access into the HE sector to influence it, and even perhaps to take it over. In developing this argument, Robinson (2012) identifies that a key aspect of the UK government was to make students central to the HE system. In doing so, she argues it placed the student as a consumer and thus created a new relationship between student and institution.

Mercer (2009) analysed the impact of new managerialism on a single department in what she described as a mid-ranking UK university. She identified accountability as a key element, alongside marketisation, efficiency and entrepreneurial activities. Within this there is a high degree of interest in how to develop transparency and if the REF is included the notion of impact. Mercer (2009) raises the question of the purpose of higher education. Similarly, O’Neill et al (2010) in a study based on business academics in an Australian University highlighted the more managerialist and market-focussed nature of the organisation, which results in a reduction in autonomy and academic freedom.

RQ3 - what impact has the rise in managerialism had on motivation of academics

\section{Methodology}

Philosophical Stance and Research Approach

The research has adopted a combined ethnographic (Bryman and Bell, 2011) and interpretivist (Saunders et al, 2009) approach, in order to investigate individuals' perception of themselves and what motivates them in their roles in their organisation. It is important in the context of the research to develop an understanding of the lived experiences and beliefs of individuals (Mickecz, 2010) and the importance that they place on them. In addition, according to Feather (2012) this use of combined philosophies will add extra validity to the research process. The research follows an inductive approach (Bryman and Bell, 2011) 
through the collection of data and the development of theory. Although there is a large literature base on the subject of motivation, there is little for academics in the UK, therefore the research is theory building (in the context that it aims to develop an applied approach to the world of academia, rather than adopting a holistic overview) rather than theory testing (Easterby-Smith et al, 2012). That said Saether (1999) would argue that the process is not pure inductive but is rather retroductive as elements of theory does exist but perhaps not in the context of the study focus. Johnston (2014) places significant emphasis on the role of theory in ensuring rigour in the research process. He emphasises the epistemological and ontological underpinnings on which the research is based as critical in supporting the approach that is to be taken. In doing so Johnston (2014) points to the need to overcome the double hurdle identified by Saunders et al (2009) of the need for academic rigour and practical relevance in management research, while Svensson (2009) points to the importance of managerial implications.

\section{Research Design}

The study follows a single case study design (Yin, 2014), making use of parallel mixed methods (Cronholm and Hjalmarsson, 2011). Studies of HEIs in the UK, often split institutions into two categories (Bessant and Mavin, 2014), chartered (pre-1992) and statuary (post 1992), and the case organisation for this study fits into the latter category. Ridder et al (2014) highlight that Case Study research is compatible with a full range of philosophical stances and as such taking a joint interpretivist and enthnographic approach fits comfortably with this view, while Thomas (2011 p68) suggests that "triangulation is almost an essential pre-requisite for using a case study approach" thus the combined use of differing philosophies coupled with the use of mixed methods will allow for detailed triangulation and as such make for an in-depth analytical perspective to take place. Further justification for a 
case study approach is provided by Radaelli et al (2014) who highlight a common critique of management research as having a limited impact on business. They highlight the need to investigate phenomena in situ and suggest the obsession for universal truth should be replaced by relevance.

Edmondson and McManus (2007) argue that whether to use quantitative or qualitative methods depends on research questions, previous research, the research design and the intended outcomes. Bluhm et al (2011) however point to what has gone before, suggesting that a new phenomenon requires qualitative based methodology, while research into established phenomenon require quantitative methods. They further emphasise the importance of qualitative methods as a method for uncovering deep meaning and is critical to gain an understanding of what individuals experience and their interpretation of that experience. Del Campo (2007) suggest a mixed methods approach as the most effective way. Krivokapic-Skoko and O'Neill (2008) suggest that the mixed methods approach brings together both systems to achieve greater rigour and creates clarification and enhancement. They particularly emphasise that this adds more depth to the research.

\section{Data Collection and Analysis}

Participants for the study were selected via a purposive sampling strategy, while also making use of convenience sampling (Avramenko, 2013). The research used a combination of a survey $(n=15)$ and semi-structured interviews $(n=5)$, following conventional practice (Alvesson and Ashcroft, 2012) starting with broad questions which focus and narrow into the topic. Interviews were transcribed to allow for analysis and interpretation. Open coding (Collis and Hussey, 2014) was used to identify key words and relationships, followed by narrative analysis (Maitlis, 2012), while the survey was analysed using basic descriptive and 
some attempt to use inferential measures to draw out the strength of relationships and to seek a causality and an existence of types. Bluhm et al (2011) suggest that studies employing multiple data collection methods have greater impact due to triangulation reassurances. Of the 15 surveys 4 were determined to be unusable due to having been incorrectly completed or not completed fully. This therefore returned a rate of $40.7 \%$ (11 surveys from a staffing of 27).

\section{Ethics}

Ethics are principles of conduct about what is right and wrong (Thomas, 2011), and it is important to conduct research in an ethical manner. Saunders and Lewis (2012 p74) define research ethics as "the appropriateness of the researchers behaviour in relation to the rights of those who become the subject of a research project or are affected by it." Key areas to address are therefore around privacy, anonymity, honesty, and confidentiality which must be all retained to ensure an ethical approach and reassure the participants. This includes issues around data security and storage. Fisher (2010) highlights the need for dis-interestedness during the data collection stage. That is not giving away personal beliefs or views on a given subject. He also warns against deception and highlights the need to get permission to record interviews (video or voice). The researcher should also attempt to avoid the misuse of the research and data, any conflicts of interest and identify ways to remain objective. That given however any interpretivist / ethnographic research will always have a subjective nature

Due to the ethnographic nature of the study and the issue that the researcher and the respondents were known to each other raised a number of these issues within carrying out the study. It was therefore imperative that all the above were considered and mediated for. In 


\section{particular the need for anonymity, honesty and confidentiality were critical in ensuring the} $\underline{\text { data collected was a fqair reflection. }}$

\section{Research Quality Issues}

Thomas, (2012) argues that reliability and validity as traditional constructs are not key issues in Case Study Research. A common criticism of Case Study (and for that qualitative research in general) is that it is not generalisable. However, Yin (2014) suggests that this is due to the obsession with statistical generalisation whereas Case Studies give you analytical generalisation, or as Tsang (2013) argues theoretical generalisation. Following on from this, Ridder et al (2014) point to the growing use of Case Study research in the development of theory. They suggest that Case Study research can allow researchers to make a "significant contribution to the field" (p374) and contribute to the wider scholarly community. This is achieved, according to Yin (2014) because Case Study research enables the development of in-depth analytical and empirical descriptions and exploration of phenomena in an organisation or organisations. Farquhar (2012) suggests that the credibility of the research rests in the philosophical assumptions that underpin it, while Levin (2012) suggests that it provides the rigorous scrutiny of experience. Supporting this Ridder et al (2014) emphasise that Case Study research tends to make a contribution in one of three ways, either by theory extension, theory refinement and theory generation. It is anticipated that the outcome of the research is likely to lead to theory extension, however that is not to suggest that there is no scope for either refinement or generation.

\section{Findings}

At a basic descriptive level 10 out of the 11 (90.9\%) respondents highlighted expertise in the top 3 scores (6 scored it highest) as the key driver. Other top high scoring driver (with 8 
respondents scoring it in the top 3 was meaning). At the other end of the spectrum, 7 respondents highlighted material reward and power as being the lowest driving force amongst them. Significantly all respondents had one of material reward and power in their bottom.

\begin{tabular}{lrrrrrrrrr} 
& Material & Power & Meaning & Expertise & Creativity & Affiliation & Autonomy & Security & Status \\
\cline { 2 - 8 } & & & & & & & & & \\
\\
Mean & 9.77 & 11.64 & 25.05 & 26.86 & 20.27 & 23.59 & 21.64 & 21.95 & 19.23 \\
Standard Error & 1.17 & 1.65 & 0.96 & 1.13 & 1.19 & 1.40 & 0.53 & 1.23 & 1.06 \\
Median & 8.5 & 10 & 24 & 27 & 21 & 24 & 21 & 22 & 19 \\
Mode & 8 & 10 & 23 & 32 & 21 & 23 & 23 & 22 & 16 \\
Standard Deviation & 3.88 & 5.46 & 3.20 & 3.76 & 3.93 & 4.64 & 1.75 & 4.08 & 3.50 \\
Sample Variance & 15.07 & 29.85 & 10.22 & 14.10 & 15.47 & 21.54 & 3.05 & 16.62 & 12.27 \\
Kurtosis & -0.57 & 1.81 & -0.31 & -0.46 & 0.82 & -0.08 & -0.21 & -0.88 & -0.52 \\
Skewness & 0.47 & 1.16 & 0.35 & -0.24 & -0.57 & -0.34 & 0.41 & -0.01 & 0.62 \\
Range & 12 & 20 & 11 & 12 & 14 & 16 & 6 & 12.5 & 11 \\
Minimum & 4 & 4 & 20 & 20 & 13 & 15 & 19 & 15 & 15 \\
Maximum & 16 & 24 & 31 & 32 & 27 & 31 & 25 & 27.5 & 26 \\
Sum & 107.5 & 128 & 275.5 & 295.5 & 223 & 259.5 & 238 & 241.5 & 211.5 \\
Count & 11 & 11 & 11 & 11 & 11 & 11 & 11 & 11 \\
Confidence Level(99.0\%) & 3.71 & 5.22 & 3.06 & 3.59 & 3.76 & 4.44 & 1.67 & 3.90 & 3.35 \\
\hline
\end{tabular}

Table 1: Descriptive Statistics

Table 1 highlights the key descriptive statistics and emphasises the initial data demonstrating the extent of expertise and the search for meaning as key drivers and the lack of power and material reward as anti-drivers. Power interestingly has the largest range influenced by one individual respondent who scored this highly as a key driver.

Table 2 demonstrates the key correlation data of each of the factors. Males tend to have a more material reward focus. 


\begin{tabular}{|c|c|c|c|c|c|c|c|c|c|c|c|c|}
\hline & Gender & Age & Service & Material & Power & Meaning & Expertise & Creativity & Affiliation & Autonomy & Security & Status \\
\hline Gender & 1 & & & & & & & & & & & \\
\hline Age & -0.14598 & 1 & & & & & & & & & & \\
\hline Service & 0.460276 & 0.568755 & 1 & & & & & & & & & \\
\hline Material & 0.649466 & -0.23816 & 0.030938 & 1 & & & & & & & & \\
\hline Power & 0.163868 & 0.38232 & 0.601876 & 0.118299 & 1 & & & & & & & \\
\hline Meaning & -0.49034 & 0.124787 & -0.20479 & -0.49662 & -0.15351 & 1 & & & & & & \\
\hline Expertise & -0.38793 & 0.441355 & -0.0718 & -0.64198 & -0.22195 & 0.548129 & 1 & & & & & \\
\hline Creativity & -0.38356 & -0.47094 & -0.52999 & -0.44913 & -0.37651 & 0.33888 & 0.498686 & 1 & & & & \\
\hline Affiliation & 0.054093 & -0.04333 & 0.206989 & 0.152515 & -0.52697 & -0.22437 & -0.3334 & -0.36717 & 1 & & & \\
\hline Autonomy & 0.225282 & -0.11136 & 0.037433 & -0.35979 & -0.16184 & 0.101679 & 0.227835 & 0.146804 & 0.035303 & 1 & & \\
\hline Security & 0.151633 & -0.37791 & -0.32519 & 0.212534 & -0.67416 & -0.41599 & -0.42332 & -0.21898 & 0.738771 & 0.046567 & 1 & \\
\hline Status & -0.08833 & 0.162067 & 0.016828 & 0.083245 & 0.673578 & -0.36043 & -0.25398 & -0.21365 & -0.57502 & -0.45072 & -0.27055 & 1 \\
\hline
\end{tabular}

Table 2: Correlation 
Information through the qualitative interviews provided some interesting insight into their perceptions and key drivers

All five of the interviewees highlighted the three elements of the role (teaching, research and administration), however one also included managing as a key element of the role. Managing was identified as managing the curriculum and did not include managing staff. Four of the five interviewees saw the key element of their role as teaching, while the other highlighted research as the key element. None focussed on administration as the key element, however of the four who focussed on teaching, three suggested that research was of growing importance and two had recently started doctoral work, while the other had completed their doctorate in the last two years. All the interviewees acknowledged keenness for the subject, and for subject expertise as crucial for entry into the profession, however only four spoke about the desire to teach and to share their knowledge through teaching as an over-riding factor. The other highlighted the desire to share their research with academic communities.

All interviewees identified the growing administrative burden as being a barrier to their role and what they hoped to achieve. They argued that excessive administration (including marking and feedback) as having a negative effect and see it as preventing them from achieving what they want to achieve. Three of the interviewees linked this to lack of protection from management (seem to focus on senior managers) and spoke about the rise of managerialism in the profession as whole but also about the growth at the case organisation. Of the five respondents none had considered leaving the profession, however one had considered leaving the organisation and had applied elsewhere for a role at a different HEI. 


\title{
Discussion
}

The two identified key drivers were expertise and search for meaning. Those seeking expertise tend to be the people who seek a high level of accomplishment in a specialised field. They work extremely hard to acquire their expertise and are both jealous and proud of it. Having established their niche they will tend not to stray outside that defined area, preferring to put their energies into maintaining and developing their capacity to perform in unusual, difficult \& specialised activities. Those seeking a search for meaning, tend to be the people who want to make the world a better place. They will only feel fulfilled if they believe that what they are doing is valuable for its own sake. Actions and choices are closely related to personal beliefs \& values and often they will make considerable sacrifices in pursuit of their aims. Their key concern is to make a contribution to something bigger, finer, greater and lasting.

There is a sense that these are intrinsic drivers and arguably fit with McClellands (Mullins, 2005) ideas and further more to Kinman and Kinman (2001) who suggest that intrinsic motivation contains both cognitive and affective elements. Arguably therefore, if they hold these intrinsic drivers as identified by Stringer et al (2011), then these result in job satisfaction and ultimately the drive for self-actualisation as identified by Maslow, which is further argued by Stringer et al (2011). It is these intrinsic drivers which we may call buttons that are pressed which charges an individual's activities and responses to certain criteria, which determines a positive or negative reaction.

\begin{abstract}
Alternatively we may consider extrinsic drivers to have a less impact on academics. Drivers with little or at least limited impact are material reward and power. Those seeking material reward tend to be people who are prepared to take on challenging, difficult or unfulfilling
\end{abstract}


roles which others may reject. Their prime motivation is to gain a material and financial base for the long term future, their key concern is often 'family security'. They are usually responsible people giving a great deal of themselves to justify the material benefits accrued. Those seeking power tend to be people who are high in self_-confidence, exuding presence and with great clarity of vision these people are determined to make things happen. That is why they want power. Their prime concern is to have impact. Uncomfortable with subordinate roles they attempt to move towards the centre of organisations to gain formal and informal power.

The rise of managerialism has had a negative impact on the motivation of lecturers. All interviewees identified the increase in management interference in the role, and highlighted that managers were becoming more directive. Those with more than five years of experience spoke negatively about the rise of managerialism, while those with less said that they had not really felt an impact, suggesting that this is the way the job is. As the institution was new to the research field they had not really been affected by the REF, however they were aware that the next REF may have a bigger impact, as the institution was starting to build a research profile. This by 3 of the 5 was felt to be a good thing.

\section{Conclusion}

Fundamentally academics are motivated by the role they undertake in society and feel that their role is a worthwhile exercise. It is evident that intrinsic drivers play a key role in that experience and in doing so they strive to contribute to society, whether that be through teaching or research. Academics are self-driven, self-motivated individuals who are focussed on what they do and what they want to achieve, whether it be through the medium of the classroom or the journal / conference. In essence this paper which reports on a small scale 
(pilot) needs to collect more data to draw more robust conclusions to enable both researchers and managers to have more reliance on the outcomes of this study. It does however suggest that there are issues to consider.

\section{Limitations}

The research has been undertaken at a small University in one faculty, and as such serves its purpose as a pilot study. It also serves the purpose set out in the methodology as a single case study, however the small nature of the study brings with it a range of limitations linked to scale and size. To that Lee and Lings (2008, p174) identify the concept of social desirability bias. That is an attempt by individuals "to present themselves in the best light possible". As with all research making use of qualitative methods, the research is reliant on the responses of the interviewee and as such relies on honest and reliable answers.

\section{Implications for Practice}

As stated earlier it is important for research to have a sound theoretical basis and to contribute to that theory. However it is also critical that research also has implications for practice, which may be described as implications for managers or management. Significantly managers of academics need to embrace the nature of the academic, the self-regulating and self-focussing element of their nature, and attempt to mould and shape how they fit into the organisation and how that meets organisational goals. It is crucial for managers to understand which buttons they need to press for individuals to respond in the way that they want them to. Managers should therefore ensure they take the time and the opportunity to develop a relationship with their staff. As such this will allow for managers to understand the drivers of the individual which is not always obvious. Academics are predominantly 
individualistic in nature, this is what partly pushes them into the role and drives their being. Too often managerialism pushes managers to treat staff holistically and this creates some of the issues which academics resist and as such affects motivation. Managers, HR and the university system needs to develop so as to allow that individualism to flourish while honing it for the benefit of the institution, and the students.

\section{Further Research}

The small scale nature of the research allows for the study to be expanded and to include more departments and / or other institutions. An increase in population and sample size will add greater sector applicability to the research. The research can also be expanded to include other educational sectors, which carry similar characteristics, such as further education or the compulsory education sector. The concepts of the psychological contract and personorganisation fit also need to be investigated alongside and in conjunction with motivational drivers. Further development may also include a discussion of the notion of work ethic, and in particular how worth ethic is portrayed and relayed in society. 


\section{References}

Alvesson, M. and Ashcraft, K.L. (2012) Interviews. In Symon, G. and Cassell, C. (Eds) Qualitative Organizational Research: Core Methods and Current Challenges. London. Sage.

Avramenko, A. (2013) Inspiration at work: is it an oxymoron? Baltic Journal of Management. Vol. 9. No. 1. pp113-130

Bathmaker, S. (1999): "So, what's the deal?" the state of the psychological contract in a 'new' university. Journal of Vocational Education \& Training, Vol 51 No. 2, pp265-282

Bessant, C. and Mavin, S. (2014) Sinking, Swimming and Thrashing about in the Deep End The Impact of University HRD Practices on the Role of the First-Line Manager-Academic in UK Business Schools. 15 ${ }^{\text {th }}$ International Conference on Human Resource Development Research and Practice. University Forum for Human Resource Development. 4-6 June, 2014. Edinburgh

Bluhm, D.J., Harman, W., Lee, T.W. and Mitchell, T.R. (2011) "Qualitative Research in Management: A Decade of Progress". Journal of Management Studies. Vol. 48, Iss. 8, pp 1866-1891

Bryman, A., and Bell, E. (2011) Business Research Methods, $3^{\text {rd }}$ Ed. Oxford University Press. Oxford.

Collis, J., and Hussey, R. (2014) Business Research: A Practical Guide for Undergraduate and Postgraduate Students, $4^{\text {th }}$ Ed. Palgrave Macmillan. London.

Creasy, R. (2013) HE lite: exploring the problematic position of HE in FECs. Journal of Further and Higher Education. Vol, 37. No. 1. pp 38-53

Cronholm, S. and Hjalmarsson, A. (2011) Experiences from Sequential Use of Mixed Methods. The Electronic Journal of Business Research Methods. Vol, 9. Iss. 2. pp 87-95

Dahl, D. W. and Smimou, K. (2011) Does motivation matter? On the relationship between perceived quality of teaching and students' motivational orientations. Managerial Finance. Vol. 37, Iss. 7, p582

DelCampo, R.G. (2007) Understanding the Psychological Contract: a direction for the future. Management Research News. Vol. 30 No. 6 pp432-440

Easterby-Smith, M., Thorpe, R., and Jackson, P. (2012). Management Research. $4^{\text {th }}$ Ed. Sage. London.

Eyal, O. and Roth, G. (2011) Principals' Leadership and Teachers' Motivation: SelfDetermination Theory Analysis. Journal of Educational Administration. Vol. 49, No. 3. pp 256-275

Edmondson, A.C. and McManus, S.E. (2007) "Methodological fit in management field research." Academy of Management Review. Vol. 32, pp 115-79 
Farquhar, J.D. (2012) Case Study Research for Business. Sage. London.

Feather, D. (2012) Oh to be a scholar - an HE in FE perspective. Journal of Further and Higher Education. Vol. 36 Iss. 2. pp 243-261

Fisher, C. (2010) Researching and Writing a Dissertation: An Essential Guide for Business Students. ${ }^{\text {rd }}$ Ed. Harlow. FT Prentice Hall.

Furnham, A., Eracleous, A. and Chamorro-Premuzic, T. (2009) Personality, motivation and job satisfaction: Hertzberg meets the Big Five. Journal of Managerial Psychology. Vol. 24, No. 8. pp.765-779

Gammie, P.G. (2006) Psychological Contracts in a Business School Context. Doctor of Education Thesis. Unpublished. University of Stirling

\section{Hackman, J.R., and Oldham, G.R. (1980) Work Redesign. Reading. Addison-Wesley}

Herzberg, F. (2003) One more time: how to motivate employees? Harvard Business Review. Vol. 81, No. 1. pp 53-62

Johnston, A. (2014) Rigour in Research: Theory in the Research Approach. European Business Review. Vol. 26, No. 3.pp

Kinman, G. and Kinman, R. (2001) The role of motivation to learn in management education. Journal of Workplace Learning. Vol. 13, No. 4. pp.132-144.

Krivokapic-Skoko, B. and O’Neill, G. (2008) University Academis' Psychological Contracts in Australia: a Mixed Methods Research Approach. The Electronic Journal of Business Research Methods. Vol. 6 Iss. 1 pp 61-72

Lawrence, S. and Jordan, P. (2009) Testing an explicit and implicit measure of motivation. International Journal of Organizational Analysis. Vol. 17, No. 2. pp 103-120

Lee, N. and Lings, I. (2008) Doing Business Research: A guide to theory and practice. London. Sage.

Levin, M., (2012) Academic Integrity in Action Research. Action Research. 10. pp 133-149. Sage

Maitlis, S. (2012) Narrative Analysis. In Symon, G. and Cassell, C. (Eds) Qualitative Organizational Research: Core Methods and Current Challenges. London. Sage.

McTavish, D. and Miller, K. (2009). Management leadership and gender representation in UK higher and further education. Gender in Management : An International Journal. Vol 24, No. 3 pp 178-194.

Mercer, J. (2009) Junior academic-manager in higher education: an untold story? International Journal of Educational Management. Vol 23. No. 4. Pp348-359. 
Mickecz, R., (2012) Interviewing Elites: Addressing Methodological Issues. Qualitative Inquiry. 18 pp482-493. Sage

Milne, P. (2007) Motivation, incentives and organisational culture. Journal of Knowledge Management. Vol. 11, No. 6. pp.28-38

O’Neill, G., Krivokapic-Skoko, B. and Dowell, D. (2010) Unpacking Informal Contractual Relationships: Psychological Contracts established by Australian Business Academics. Irish Journal of Management. Vol. 29, No. 2, pp 5-33

Parr, C. (2014) Is your university a good place to work? Times Higher Education. 30 Jan. - 5 Feb. No. 2137

Radaelli, G., Guerci, M., Cirelli, S. and Shani, A.B. (2014) Intervention Research as Management Research in Practice: Learning from a Case in the Fashion Design Industry. British Journal of Management. Vol. 25. No. 2. Pp 335-351.

Ridder, H-G., Hoon, C. and McCandless Baluch, A. (2014) Entering a Dialogue: Positioning Case Study Finding towards Theory. British Journal of Management. Vol. 25, No. 2. Pp 373387

Robinson, C. (2012) Student Experience: What does this mean in practice in the context of higher education institutions. Journal of Applied Research in Higher Education. Vol 4. No. 2. Pp 84-108

Rowley, J. (1996) Motivation and academic staff in higher education. Quality Assurance in Education: An International Perspective. Vol. 4, Iss. 3. pp 11-16

Saether, B. (1999) "Retroduction: an alternative strategy?" Business Strategy and the Environment. Vol. 17, Iss. 4, pp 245-249

Saunders, M., Lewis, P., and Thornhill, A. (2009). Research Methods for Business Students. $5^{\text {th }}$ Ed. Prentice Hall. Harlow.

Saunders, M., and Lewis, P. (2012). Doing Research in Business \& Management: An essential guide to planning your project. Prentice Hall. Harlow.

Schimmel, T., Johnston, P. C. and Stasio, M. (2013) Can “collegiality” be measured?: Further validation of a faculty assessment model of discretionary behaviours. Vol, 21. August [online] Available at: http://www.aabmc.com/manuscripts/131586.pdf

Stringer, C., Didham, J. and Theivananthampillai, P. (2011) Motivation, pay satisfaction, and job satisfaction of front-line employees. Qualitative Research in Accounting \& Management. Vol. 8, Iss. 2, pp161-179

Swift, M., Balkin, D.B. and Matusik, S.F. (2010) Goal orientations and the motivation to share knowledge. Journal of Knowledge Management, Vol. 14, No. 3. pp.378-393 
Sukirno, D.S. and Sienghai, S. (2011) Does participative decision making affect lecturer performance in higher education? International Journal of Educational Management. Vol. 25, No. 5. pp 494-508

Svensson, G. (2009) "A Counter-intuitive View of the deductive research process: clockwise versus anti-clockwise approaches." European Business Review. Vol. 21, No. 2, pp 191-196

Thomas, G. (2012). How to do your Case Study: A Guide for students and researchers. London. Sage.

Tsang, E.W.K. (2013) Generalizing from Research Findings: The Merits of Case Studies. International Journal of Management Reviews. DOI: 10.1111/ijmr 12024.

Wilkesmann, U., and Schmid, C.J. (2014) Intrinsic and internalized modes of teaching motivation. Evidence-based HRM: a Global Forum for Empirical Scholarship. Vol. 2, No. 1. pp 6-27

Yin, R.K. (2014) Case Study Research: Design and Methods. $5^{\text {th }}$ Ed. London. Sage. 